\title{
THE GOVER NING BODY OF THE CHURCH IN WALES: RECENT LEGISLATION
}

\author{
THOMAS GLYN WATKIN
}

\author{
Legal Assistant to the Governing Body
}

The April meeting of the Governing Body of the Church in Wales at St David's University College, Lampeter, had an agenda packed full of legal business. However, it will probably be remembered for the measures that it rejected rather than for those which it actually passed.

As part of the Report of the Standing Committee, it was recommended that an age limit of 70 be introduced for the Governing Body, all its committees, the Board of Mission, the Representative Body, atll its committees, the Provincial Patronage Board, all committees reporting to the Bench of Bishops and the Cathedrals and Churches Commission. This motion was defeated by 153 votes to 123 . The general retiring age therefore remains at 75 . although ex officio clerical members, that is Bishops, Deans and Archdeacons, continue to have to retire at 70.

The Governing Body did however agree to chairmen of the divisions of the Board of Mission becoming ex officio members of the Governing Body.

It was also agreed that the power of the Archbishop of Canterbury to provide for the appointment of diocesan bishops in Wales. and even for the appointment of the Archbishop of Wales, in certain circumstances should cease. Since Disestablishment in 1920, if the electoral college failed to reach a decision after meeting for three days. or if it failed to meet within three months of a see becoming vacant. or if the college's choice was vetoed by the Sacred Synod of diocesan bishops. the choice passed to the Primate of All England. The Governing Body has now decided that in the first two of these cases. the choice shall now pass instead to the Bench of Bishops of the Church in Wales. However, in the last of the three cases. where it is the bishops who have in effect vetoed the appointment because they are not satisfied in Synod of the fitness of the Bishop-Elect, the Governing Body has decided that the electoral college shall be reconvened and a fresh election shall take place. Suffice to say that none of these three scenarios has ever arisen in the history of the Church in Wales. The Governing Body also agreed to extend the time allowed for a Bishop- or an Archbishop-Elect to accept his appointment from 21 days to 42 days.

The Governing Body also approved new Church Fubric Regulations. Redundant Churches Regulations, and Regulations Gorerning the Application of the Proceeds of Sale of Churches. Church Sites and Churchyards. Yet at further amendment was made to the celebrated regulation 15 (1) (c) of the Churdhard Re'gulations. dealing with inscriptions on tombstones. This section is probabls the most amended section in the whole of the Constitution. It is now permitted for grasestones to hear one or more or all of the following: a simple cross. a simple and appropriate inscription. an appropriate motif. All of these regulations now go into Volume II of the Constitution. The Governing Body also approved in principle the new Constirutionit of Diocesan Churches and Pastoral Committees. This now goes to the Drafting SubCommittee for its wording to be settled and a Welsh version prepared before being placed in Volume II after final approval at the next Governing Body meeting.

As well as these various amendments to the Constitution. the Governing Body had before it in April several Bills. It gave a first reading, title only, to a Bill to Establish a Permanent Archiepiscopal See. This will have its second reading. a debate on its principles, in September. The Bill provides for Llandaff to become the permanent archiepiscopal see. Currently. the metropolitical see goes to the diocese of which the archbishop is diocesan. 
The Governing Body received the report of the Select Committee it had established on the Bill to Amend Chapter XI of the Constitution. and gave this Bill its Committee Stage, Report Stage and voted upon it. The Bill was duly passed by twothirds majorities in all three orders. It therefore becomes a Canon of the Church in Wales and the amendments contained therein to Chapter XI of the Constitution take effect. These provide for the appointment of deputy chancellors and deputy registrars, and for the payment of the latter. The Canon also provides for changes to faculty jurisdiction within the Church in Wales. In future. faculty procedure is to apply to consecrated churches and land vested in either the Representative Body, Diocesan Boards of Finance or other trustees who agree to be so bound, but will also apply to unconsecrated churches. churchyards and burial grounds if these are listed as being of special architectural or historic interest or are situated in a conservation area or have been subjected to faculty procedure by decree of the diocesan bishop. Faculty procedure continues to be inapplicable to cathedrals and their churchyards. Where a bishop has decreed that faculty procedure shall apply in circumstances where it otherwise would not. it is open for him to deregulate the church or churchyard at a future date, also by written decree. Where faculty procedure applies, a faculty is required for a change of use (other than to use by another denomination under the Sharing of Church Buildings Act 1969); alterations, additions, repairs, decoration. redecoration, demolition or removals from church fabric or land; the introduction. removal, alteration or repositioning of furniture, fittings, murals, monuments, plate and precious objects, or any repair to them, excluding loans to museums and like institutions; acquisitions of permanent or exclusive rights of burial; and for the removal of human remains from existing burial spaces. Exemption from faculty procedure is provided where the matters are dealt with by the Churchlards Regulations, where the work is urgent for reasons of safety or for the preservation of the building, and in relation to various minor matters listed in the Faculty Rules in Volume II of the Constitution. These rules, being part of the Rules of the Diocesan Courts. provide for the manner in which faculty procedure shall operate in practice. The new Canon sets out the limits of faculty jurisdiction.

Two other Bills had been set down to receive their Committee Stages. Report and Vote in April. These were the Bill to Amend the Discipline of the Church in Wales Regarding Remarriage after Divorce and the Bill to Remove Doubt Concerning Marriage after Divorce as an Impediment to Admission to Holy Orders. The former sought to introduce a new discipline under which clergy would be permitted by their diocesan bishop to remarry divorcees during the lifetime of a previous spouse provided the bishop's permission was given in writing. The Bishops were to introduce and develop guidelines to govern such cases, while the right of clergy with conscientious objection to refuse to solemnize such marriages or to allow their churches to be used for such ceremonies was explicitly upheld in conformity with the Matrimonial Causes Act 1965. The Bill however was defeated, failing to obtain the requisite twothirds majority in the Order of Clergy, after a dramatic, cliff-hanging recount. The voting was:

$\begin{array}{lrc} & F o r & \text { Against } \\ \text { Bishops } & 6 & 0 \\ \text { Clergy } & 74 & 39 \\ \text { Laity } & 109 & 51\end{array}$

The Church in Wales therefore continues its discipline of prohibiting all such remarriages. This leaves unanswered an intriguing legal question. Until now. the discipline has been based upon clerics being instructed by their diocesan bishops not to perform such marriages, the clerics being bound to conform as a matter of canonical obedience and the Welsh bishops having agreed to maintain uniformity of practice. Hitherto, undoubtedly. one or more bishops could have changed their approach. 
The question is now whether they are still free to do so given the Governing Body has refused to sanction such a change.

Following the defeat of the first divorce Bill, the Governing Body agreed to postpone the Committee Stage of the second, relating to ordinations, until the Bench of Bishops had had an opportunity to consider the implications of the situation that had arisen.

The defeat of the Remarriage after Divorce Bill in the Order of Clergy has revived concern about the fate of the Bill to Permit Women to be Ordained as Priests which is scheduled to receive its final stages at this year's September meeting. The last such Bill also failed in the Order of Clergy. Questions are again being raised as to the merits of Bill procedure generally, and the Governing Body in April did sanction, within the current rules of Bill procedure, a more flexible approach to dealing with questions of liturgical revision and experiment. A Working Group on the Constitution is currently charged with considering this vexed question and is expected to report to the Standing Committee in 1997.

\section{LONDON MEETINGS}

Meetings are held in 'Briefs', 7 Stone Buildings, Lincoln's Inn, 5.30 p.m.

Wednesday 11 September 1996

'The Visitation of York Minster, 1841: the flaring of a dying candle?'

The Revd M. G. Smith, M.A., B.D. (Oxon), Former Rector of Silverton

Wednesday 13 November 1996

'The Manchester Chronicles:' the disputes between Samuel Peploe and the Chapter of the Collegiate Church of Christ, 1718-43
Roger Turner, Esq., M.A., B.D., M.TH., Barrister-at-Law

Visiting Research Fellow, Institute of Historical Research

Wednesday 8 January 1997

'Simulation-A Heading of Nullity'

The Revd Fr Richard Moth, M.A., J.C.L., K.H.S. President of the Southwark Metropolitan Appeal Tribunal

Members and non-members are all welcome

for further details, contact Paul Barber (0181-299 4380) 